Article

\title{
Alternative Approaches of Summer Milk Sales from Transhumant Sheep and Goat Farms: A Case Study from Northern Greece
}

\author{
Athanasios Ragkos ${ }^{1, *}$, Alexandros Theodoridis ${ }^{2}(\mathbb{D})$ and Georgios Arsenos ${ }^{2}$ \\ 1 Agricultural Economics Research Institute, Hellenic Agriculture Organization "Demeter", \\ 11528 Athens, Greece \\ 2 School of Veterinary Medicine, Aristotle University of Thessaloniki, 54124 Thessaloniki, Greece; \\ alextheod@vet.auth.gr (A.T.); arsenosg@vet.auth.gr (G.A.) \\ * Correspondence: ragkos@agreri.gr; Tel.: +30-210-2755086 (int. 8)
}

Received: 21 August 2019; Accepted: 11 October 2019; Published: 13 October 2019

\begin{abstract}
Sheep and goat transhumance provides a wide range of ecosystem services (ES). Transhumance-specific dairy products could function as a nexus between the system and the public, incorporating ES which are not remunerated in markets, but in Greece, there are actually no such dairy products. Within this context, the objective of this paper was to present a case study regarding a comparative assessment of three different approaches (supply chains) in milk sales from transhumant farms. The first involved production of cheese on-farm and direct sales to consumers. In the second approach, farmers sold their milk to the same industry throughout the year, where it was mixed with milk from non-transhumant farms. The third approach concerned cheese produced solely from milk of transhumant flocks in a small dairy in the highlands. An assessment framework was developed examining the perceived quality; economic performance of farms; compatibility and; representativeness and contribution of each approach. Based on five in-depth interviews with farmers and dairies, it was found that a combination of the three approaches would be beneficial for farms-to decrease risks-and for the system as a whole, in order to convey the 'agro-pastoral message' to wider audiences and to increase the recognisability of transhumance. In addition, the analysis showed that the economic performance of each approach was related more to managerial issues and organizational requirements rather than to the achievement of higher prices and more added value in the first and third approach.
\end{abstract}

Keywords: agro-pastoralism; specific dairy products; livestock farms economic performance

\section{Introduction}

Transhumance is the annual circular movement of livestock between winter and summer rangelands [1-6]. Flocks leave lowlands in spring and spend 4-6 months grazing in natural mountain rangelands, in order to avoid high summer temperatures $[7,8]$. In particular, sheep and goat transhumance constitutes a system with multiple actors with complex interactions at all links of the supply chain (SC) until products reach consumers. It is also a specific type of agro-pastoral (pasture-based) systems, thus it shares many common characteristics with them [9]. Sheep and goat transhumance is typical for Mediterranean settings, for instance in France (Alps and Pyrenees), Spain and Italy, while there is also transhumance in the Balkans (Bulgaria, Albania, North Macedonia) and in Turkey (mainly for meat) [9]. In the Greek setting, it is still practiced throughout the country $[10,11]$, as it pertains to the climate conditions and geography of its mountainous, disadvantaged and marginal areas [12] and it is the activity that has kept many rural areas alive, while its cultural heritage has been a factor shaping their socio-economic development trajectories [13]. 
Nowadays, there are 3051 transhumant flocks in Greece, which rear approximately 1.1 million sheep and goats (2011) (about 7.5\% of the sheep and goat population). More information about the structure of transhumance are available in [10].

A recent study [7] showed that the economic performance of Greek sheep and goat transhumance is low-when subsidies are not considered-although, the same was also reported for intensive production [14]. This is mainly due to low productivity and low product prices, which counterbalance cost savings closely related to their extensive character, as in summer flocks are kept outdoors almost all day and graze freely in High Nature Value grasslands with considerable floristic diversity, with no supplementary feeding $[7,15,16]$. In lowlands, sheep are fed indoors with forage and concentrates and only graze for a few hours a day, according to weather conditions, in natural or irrigated grasslands. Transhumance dairy products often have excellent quality and organoleptic characteristics [17] and especially the milk produced in summer is of higher quality, as it has high concentration of Conjugated Linoleic Acid and low $\omega 6 / \omega 3$ ratio because of grazing in mountain rangelands [18].

In addition to its economic role, transhumance is responsible for the provision of multiple ecosystem services (ES). Following the definition of [19], ES are all the outputs of natural production systems and ecosystems that are of relevance to society. Although the scientific literature about transhumance is relatively limited (for instance [20]), there are several sources examining the provision of ES from agro-pastoral systems in general (see [21] for a comprehensive discussion and also [22,23]). ES can be categorized in four types [19]: Provisioning ES [15,24-26], regulating ES [20,27,28], cultural ES $[12,23,29,30]$ and supporting ES [31]. The issue with ES is that in many occasions they are externalities and/or public goods (such as the regulating, cultural and supporting ES [23]), so their implications are not perceived directly by society. The provision of such goods and services is often referred to as 'multifunctionality' of agro-pastoralism [32-34]. Agro-pastoral (and transhumant) farmers are not remunerated for the ES that they provide to society [21,22] through the market prices they receive for their products [35]. Targeted policy frameworks have been proposed to counterbalance such market failures, namely the 'Payments for Ecosystem Services' in Spain [36,37], or even more generic ones, such as Pillar II measures of the Common Agricultural Policy (CAP) regarding protected areas, mountainous areas, organic farming etc. However, the implementation of such measures in Greece has been rather generic, not targeting transhumance and its particular issues [38], or has increased the dependence of these farms on policy support, rendering them more vulnerable to changes [39].

An alternative to such policy-driven solutions would be the introduction of innovative transhumance-specific products, which would reflect and incorporate the whole range of ES provided by it. In Europe there are examples of cheeses which are partially connected to transhumance or other types of seasonal movements of flocks, such as 'Idiazabal' in the Basque country (Spain) and Ossau-Iraty in the Pyrenees (France). In Greece, however, dairy products exclusively from milk of transhumant flocks are lacking, as most industries mix this milk with milk of other farms for conventional dairy products. Indeed, low production volumes and brief milking periods in summer render a separate production line for transhumance products economically unviable under current conditions, while transportation costs from the mountains to the lowlands are sometimes excessive and industries avoid to collect this milk, which is also the case in France [40]. As a result, there are no Greek dairy products connected explicitly to transhumance, consumers remain unaware of its multiple ES and transhumance is cut off the market. [41] used the term 'disemebeddedness', as opposed to 'social embeddedness' in order to describe such phenomena of ".....loss of uniqueness and identity...." of products due to the fact that they are disconnected from their origin. The latter term rather describes the degree to which a product is integrated to the place and its particular characteristics and has been reported as a factor which nurtures economic activity by building on trust [42,43]. Obviously, 'disembeddedness' aggravates the already low economic performance of farms and jeopardizes their viability and the provision of ES.

To mitigate these effects, specific products could serve as a nexus to stimulate awareness about transhumance in the general public and to valorize production up to its true potential $[44,45]$. In the 
European Union, there are certification schemes linking, for instance, the whole production process (Protected Designation of Origin - PDO) or at least part of it (Protected Geographical Indication - PGI) or with the area of origin [46]. 'Mountain' production [47] is another example of the sort, optionally certifying products from areas designated as 'mountain' by national rules.

The role of such certifications has been described in the broader sense of connecting the area to the premium characteristics of the product-stimulating rural development and benefits for local populations-and is thus connected to 'some aspect of reterritorialization', linking products only to a lesser degree to the production practices [48]. They also add the dimension of 'natural capital' to transhumance products, in the sense that they pinpoint a connection between the product and local vegetation and other environmental characteristics. The same also stands for 'Traditional Specialty Guaranteed' [49], a term which characterizes products with traditional ingredients and production methods, but still connects them to a particular area and for the 'grass-fed' scheme [50], which is predominantly applied to beef meat [51] but is also gaining attention for dairy products [52]. In this context, specific products constitute an integral part of 'territorial development' [53] which ".... refers to integrated multisector development across a specific portion of territory, guided by a spatial vision of the desirable future ...... makes no reference to scales (local, regional, national or transnational) and applies equally to any of them" [54]. The other pillar of territorial development is social capital [55] — which is reflected in governance —and the combination of the two pillars leads to sustainable development. Embeddedness and territorial development are clearly interconnected, as the activity of parties involved leads to 'territorial embeddedness' " ... ... being created and re-created" [56], which renders a bipolar consideration of embeddedness and disembeddedness quite difficult [56]. Apart from the territorial aspect, PDO, PGI and 'mountain' certifications also constitute marketing tools to maintain product reputation, penetrate new markets and to protect them from unfair competition [57-59].

Despite some level of 'embeddedness', transhumance-specific cheese does not fully pertain to such certification schemes, as in this case production is undeniably linked to the territory but also to the specific practices of transhumant farms and to their cultural heritage and traditional character, which are not area-specific. Furthermore, although Greek consumers have been reported to be willing to pay more for certified products [60-63], basic notions reflected in them-such as tradition and locality-in some cases have been used in an arbitrary and misleading way [64], in order to increase the social embeddedness of products which have no clear connections with respective territories [41]. In order to ensure benefits, transhumance-specific production should ideally lead to an overall marketing strategy to promote existing identities, expressing the deep linkages between practices, local culture and governance [41]. A closer connection of this sort could be achieved through 'short supply chains', a term which embraces different types of SCs $[41,59]$. Their characteristics vary across regions and countries [65], but they commonly aim to reduce the physical distance between consumers and producers, thus helping to maintain the specific identity of production $[59,65]$. Short SCs have been developed in parallel to conventional ones and have entail benefits in terms of added value for producers and product recognizability, helping to protect vulnerable local production systems from global market competition [66].For this reason, short SCs are targeted by the CAP and are an issue of academic debate and discussion [59]. Nonetheless, conventional SCs have also considerable mid- and long-term advantages $[59,67]$, so a question arises regarding the best way for transhumance products to reach the consumer but also the implications of adopting such a quality approach at the primary production (farm) level.

This paper presents the findings of a case study regarding a comparative assessment of three different approaches in summer milk marketing from transhumant farms. The first approach ('Peasant') included cheese production on-farm (especially in summer) and direct sales to consumers; the second ('Conventional') involved the continuation of the same marketing of milk throughout the year (farmers continued to sale their milk to the same industry, where it was mixed with milk from other farms); and the third ('Artisanal') was the production of cheese solely from milk from transhumant flocks in 
a dairy situated in the highlands. Each of these approaches was linked to a specific SC. Necessary information to understand the key issues governing the operation and performance of each SC was collected through in-depth interviews with three farmers, one from each SC, and two dairies, one typical of the 'Conventional' SC and one of the 'Artisanal'. A framework was developed aiming to assess the effects (direct or indirect) of the three SCs on primary production (farm-level specificities) and on the way that the final product was perceived and contributed to broader objectives linked to transhumance.

\section{Materials and Methods}

\subsection{Profile of the Three Supply Chains}

Supply Chain 1 ('Peasant') involves the production of cheese and other dairy products on-farm and direct sales to consumers. This is a usual and rather traditional activity for semi-extensive sheep and goat farms. Even from past decades, transhumant farmers produced cheese during their movements from lowlands to the highlands and sold them to consumers in large villages and cities across their pathways [68]. Nowadays, this SC involves cheese production as a means of economic transactions (for instance, as rent for a rangeland or a land parcel) or as a market-oriented activity. In the latter case, it constitutes an effort to increase income and financial stability [69]. On-farm milk transformation is sometimes dictated by lack of processing infrastructure, for instance this has been reported for Agrafa area in Central Greece (personal communication) and also for France in the period after mid-July, because large industries choose not to collect it [40]. Until a few years ago, it was rather complex to produce and sell cheese on-farm, but Law 4056/2012 and of Common Ministerial Decision 3724/162303/22-12-2014 simplified the process. In particular, farmers can obtain a license for their on-farm dairy from their Regional Government, provided that their farms comply to sanitary requirements set by the Greek law. However, compared to legal requirements for dairy industries, the framework is flexible when it comes-for instance-to construction materials and the maturation and drying process, including the use of barrels. The only restrictions which apply is that the cheese-making room should be discrete from the rest of the farm (e.g. a cabin) and that all equipment should be in line with Reg. EC/852/2004 for flexibility in the application of HACCP principles. In addition, farm dairies can only transform 300-500 kg milk daily. For these reasons, the total investment costs for an on-farm dairy are significantly lower than those for the establishment of a larger dairy industry. In this SC, the involvement of middlemen (dairies, retailers, restaurants) is rare. Cheese makers are usually women, who have traditional know-how from older family members $[70,71]$, but lately young members of transhumant families have started to follow cheese-making courses in public or private schools in order to undertake on-farm cheese-making in a more systematic and professional way.

Supply Chain 2 ('Conventional') is the most usual for Greek sheep and goat farms and also for transhumance during winter. In general, farmers sell milk directly to industries, but there are several characteristics and practices (e.g. level of intensification and farm size, feeding and other production practices, size and capacity of industries, dairy products, etc.) which generate a diversity of specific value chains. Actually, there are 543 dairy industries throughout Greece, most of which produce sheep and goat cheeses. 'Conventional' dairies are governed by stricter sanitary requirements and their buildings should conform with specific guidelines (Presidential Decree 79/2007/FEK A95 implementing European Legislation (Reg. EC178/2002, 852/2004, 853/2004, 882/2004; Law 4325/2014)) and because of that, investment requirements are higher. Industries have developed own distribution networks and target specific retailers and consumers or even the general public. Another characteristic of importance is the degree of formalization of professional relationships. Signed contracts are usual between farmers and industries [72] and even when there are no such contracts, agreements are based on mutual trust. Industries in this SC are increasingly becoming export-oriented and certify their products and processes, while farmers usually produce cheese only for household consumption or gifts. This SC, 
being mainstream, provides transhumant farmers the same benefits as sedentary farmers, however similar SCs have been connected to low and declining farm incomes [59,67].

Supply Chain 3 ('Artisanal'), on the other hand, is not very usual in Greece. It involves selling milk to small local dairies with limited capacity, infrastructure and resources. These are usually situated in semi-mountainous or highland areas, relatively away from major consumption centers, and produce a variety of local specific cheeses, usually maintaining traditional know-how and processes. Due to their low capacity, they transform milk of only few farms. Similar to 'Peasant', this SC is sometimes obligatory, when large dairy industries do not decide to undertake milk transformation (due to distance or in summer) [40]. Since they have limited resources, they undertake other marketing functions such as product transportation and sales. Usually dairies sell directly to consumers or to small delicatessen stores and other retailers in cities nearby and, more rarely, to major cities in Greece.

All three SCs are subject to veterinary restrictions to ensure product quality, which are common for farms irrespective from their production system. Transhumant flocks need to acquire a 'movement' license from the local Veterinary Office, which confirms that flocks are disease-free. Milk is collected from milk coolers and transported to industries with trucks in SC2, will for SC1 it is transformed on-farm and in SC3 transportation distance is about $500 \mathrm{~m}$. Milk from all farms is tested regularly for Somatic Cell Count and Total Bacterial Count by the National competent body (Hellenic Agriculture Organization "Demeter"). Moreover, cheese production from raw milk is not allowed in Greece unless permission is provided from Veterinary authorities and applies only to cheeses matured for two months or more.

The identification of these three SCs falls within the categorization described by [73] in [59]. 'Peasant' SC resembles to 'Face-to-face' sales directly to consumers; 'Artisanal' SC is close to 'Spatially proximate', targeting local markets and consumers aware of the local character of products; 'Conventional' SC is parallel to 'Spatially extended', where sales are more or less anonymous and consumers are not aware of the area or production practices ('disembeddedness'). These three SCs are also the main ones in other Mediterranean countries, with comparable relative importance. According to a recent review [40] for France, Greece, Italy and Spain, 'Conventional' was the prevailing one in all countries, being responsible for over $85 \%$ of milk transformation, while in Italy, the percentage of sheep and goat milk processed in large industries has increased significantly from 2002 onwards. 'Artisanal' SCs are typical for goat production [74], accounting for 22\% in France and for almost 10\% in Spain [40]. Obviously, 'Peasant' and 'Artisanal' SCs pertain more to the example of short SCs [65].

\subsection{Methodological Framework}

The analysis in this paper was based on a case study of a mountain area (Northern Pindus) in Northern Greece. Apart from budget and time restrictions, the choice of this particular methodological approach was based on the fact that a case study could yield important in-depth information towards a better understanding of key issues governing the operation of alternative SCs (see [75] for a richer discussion about case studies). In addition, the choice of farms and dairies in the survey was not random, as they were all typical of their respective SCs and all participants were very keen to discuss in-depth and to provide crucial information to understand not only the operation of each SC but also the trends of the sector as a whole. Furthermore, 'Peasant' and 'Artisanal' farms are not very usual in Greece-there are only a few farms producing cheese and only a very small percentage sells cheese systematically or transforms a large part of their total milk production-so it was preferred to do in-depth interviews with representative ones in order to obtain a deeper understanding for their dynamics. Moreover, it was decided to provide a comparative analysis of typical 'real-life' farms (not 'average' ones) with similar sizes and production technologies: Transhumant farms, semi-intensive in winter and extensively grazing in summer, rearing local sheep breeds. Examples of this methodological approach in SC research include the work of [45] who presented the results of interviews with six case study SMEs, two for each one of three food supply chains. [76] followed a case study approach, with six 
interviews of meat farmers/sellers representing slightly different marketing approaches and [77] presented the quantitative findings of a case study with 33 participants.

The case study in this paper involved on-site research in three mountain communities of the case study area. Pindus is the biggest and most important mountain range in Greece and its Northern part, where the case study was undertaken, is typical of the Greek transhumance sector. The particular area of the case study is in the border of three Regions (Western Macedonia, Thessaly, Epirus), but exhibits considerable homogeneity in terms of livestock production, pseudo-alpine rangelands grazed from late May until October, distance from big cities and significant cultural heritage related to transhumance. Sheep and goat production and - to a lesser degree -tourism are the only economic activities and during winter the area is significantly depopulated. Apart from its representativeness, this territory was chosen because it hosts a large number of transhumant flocks in summer (see [10] for more details) and also has adequate milk processing infrastructure, so all three SCs under examination are present-yes, in different degrees.

The research methodology comprised three steps. The first involved a detailed profiling of the three SCs, describing how farms and respective dairies operated as well as their history and organization. The second included a qualitative analysis of the motivation of farms to adopt their specific SC and of the corresponding strategies of dairies. Based on the interviews, the analysis built on specific statements of respondents and on their choices regarding the use of labor and the sales of products, as well as on an assessment of the relationships and interactions between the two types of actors. The third step was a farm-level technical and economic analysis, by means of which differences in the use of resources, the revenues and production costs as well as the overall economic performance of farms and its relationship to the choice of the specific SC were examined. These three steps were consolidated through a qualitative comparative assessment framework with the following points.

- Perceived quality of final (manufactured dairy) product. This point referred to the degree to which the physical properties of milk as well as the positive effects of the ES provided by transhumance were reflected in the final product. Therefore, this point was not restricted to common food quality features such as healthiness, composition, taste, smell, etc., [41,65] but also to broader quality perceptions of consumers regarding culture, use of resources and the territory ('terroir') of production [48], thus highlighting their 'embeddedness' to transhumance and respective territories. As already explained, the high quality summer milk of transhumant flocks is the result of grazing in High Nature Value land [10] and is linked to a rich socio-historic background [15,78,79]. The incorporation of these characteristics to the dairy product could contribute towards the survival and continuation of transhumance.

- Economic performance. [80] proposed that profitability constituted an important characteristic to measure the success of an SC, especially in terms of price difference with other products and of overall turnover. [77,81] reported economic benefits from short SCs and [59] proclaimed a 'squeeze' of farm incomes in conventional SCs, but [67] argued that such 'absolute' economic benefits had not actually been confirmed in practice. Therefore, the choice of one of the three SCs in order to achieve high revenues is generally not easy for transhumant farmers and requires a detailed examination of the economic performance of farms having already adopted this specific approach - in terms of revenues and expenses - and an assessment of the arrangements they have made to accommodate this choice. Thus, it is not a priori certain that a seemingly rational decision will have positive results.

- Compatibility. The choice of one of the three SCs is expected to affect the organization of farms, their production practices, farmers' lifestyles etc. For example, each SC entails common but also different standards for products, based either on traditional tacit knowledge or on formal quality assurance and certification. Short SCs presuppose more interaction with consumers 'rather than solely an exchange of a product' $[43,59,67]$, which can be proven time-consuming for farmers, and also require the development of a common communication forum. In addition, changes in feeding strategies and reproduction -in order to adjust the lactation period-may be needed, but this could be contrary to family habits. Transhumance has a symbolic value, corresponding to the search for a harmonious 
combination between tradition, social life and rural organization-more even than what has been described for other farming activities [82] — the choice of a SC incompatible with such characteristics would probably not be successful. In their analysis [83] discerned between 'profit sufficers' and 'profit maximizers' to stress this point. [44] argued that the evolution of agro-pastoral production and its integration to market competition compelled farmers to give up part of their identity and that these 'modern' products differed from original 'agro-pastoral products', much like what [41] described as the “.....construction of a new identity...." for 'disembedded' products.

- Representativeness and Contribution. Notoriety and representativeness of a product constitute important assets for success of a specific SC [80] and this particular point examines whether a SC is able to reach wider audiences or to raise awareness of interested consumers towards transhumance, the ES it provides and the benefits they entail. Short SCs in many cases involve closer relationships between farmers and consumers [59], thus assisting to convey messages of culture, origin and specificity. This way, increased knowledge of consumers could be transformed to a behavioral change [67]. Nonetheless, since this effect has been reported as a 'welcomed by-product rather than a private motivation' [67], the role of short SCs in the 'embeddedness' of local production should be examined in more detail, in conjunction to the 'Conventional' approach.

The necessary information and data for this study were collected through in-depth interviews with three farmers, one from each SC, and representatives of two dairies, one 'Conventional' and one 'Artisanal'. For this reason, two different questionnaires were designed. The first was used for interviews with farmers in order to record farm profile; potential existence of traditional tacit knowledge in cheese making (family or community level); advantages and problems from their choice of a specific SC; requirements of this SC in infrastructure, farm organization and investments; labor management; relationships with dairies and other actors across the SC. Since perceptions of economic performance may differ across actors [67], it was decided to also collect technical and economic farm management data (product yields and prices, fixed capital endowments, variable capital use, land cultivation and related expenses, purchased feedstuff, use of rangelands per period) in order to generate objective indicators of economic performance. The second questionnaire was used for interviews with representatives of dairies. Questions were organized in separate Sections regarding the profile of the company and business organization; collaboration with transhumant farmers and potential benefits and problems; perceptions of the quality of milk from transhumant farms; market prospects of these products.

\section{Results}

\subsection{Profile of Survey Participants}

\subsubsection{Profile of the Three Farms}

Farm 1 ('Peasant') (660 dairy ewes) was situated in a mountainous village of Epirus and in summer animals grazed in higher altitudes, performing a small vertical movement of about $20 \mathrm{~km}$ ('transterminance'). The village had 175 inhabitants, most of which were involved in the primary sector or were pensioners, and hosted 2800 transhumant sheep and goats in summer, owned by seven families. Sheep were of an endangered autochthonous breed ('Katsika'), supported under Measures 10.1 and 10.2 of the Rural Development Program of Greece 2014-2020. The farmer produced local cheeses in summer (e.g. galotyri) with traditional techniques and sold directly to consumers and to local retailers, but also a small part of his milk would go to the same dairy industry as in winter (Figure 1). 


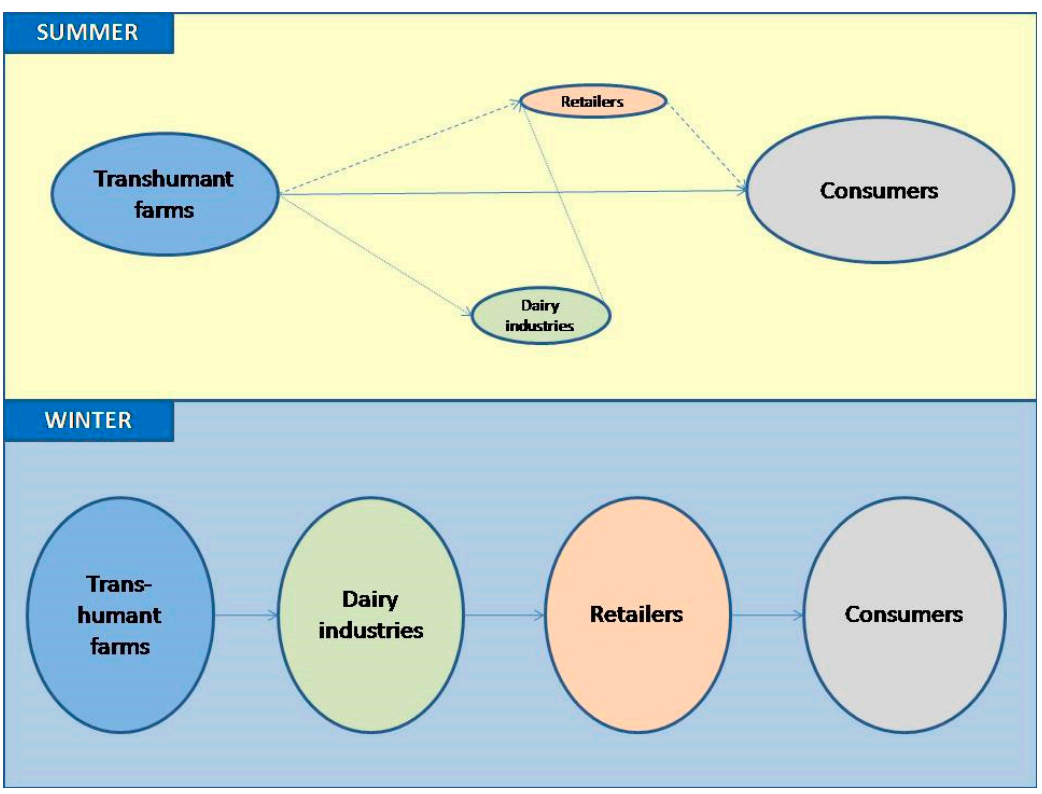

Figure 1. Illustration of the 'Peasant' supply chain in the case study.

Farm 2 ('Conventional') (570 dairy ewes) (Figure 2) sold to the same industry throughout the year (winter and summer). Sheep were of another autochthonous endangered Greek breed (Kalaritiki), also supported under the same framework as 'Peasant' farm. The farm transformed a small quantity of milk to cheese in summer only for household consumption. The distance between summer and winter rangelands was about $140 \mathrm{~km}$. The mountain community was deserted in winter but had non-negligible tourism infrastructure (a hostel and several restaurants) and was also the summer domicile of about 10,000 sheep and goats belonging to about 25 families.

\section{SUMMER - WINTER}

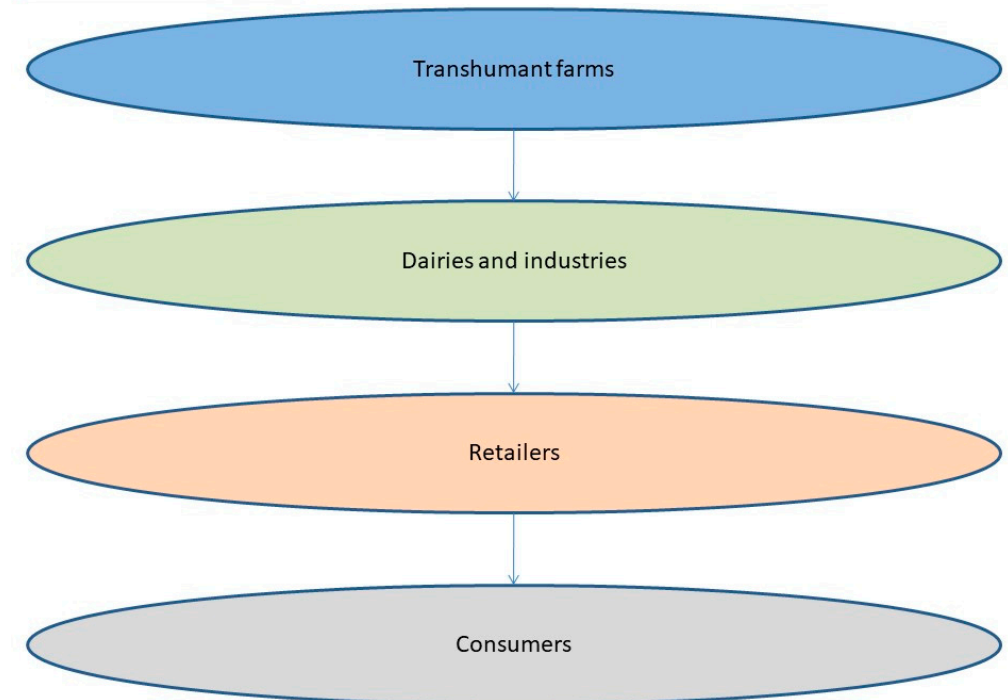

Figure 2. Illustration of the 'Conventional' supply chain in the case study.

Farm 3 ('Artisanal') (600 dairy ewes) sold milk to a small dairy in the highlands which operated only in summer with milk of transhumant flocks (Figure 3). Sheep were crossbreeds of two Greek breeds (Karagkouniko and Frizarta). The distance between summer and winter rangelands was about $160 \mathrm{~km}$ and the farmer also cultivated land in the lowlands for feedstuff. The farm kept a small quantity 
of milk in summer for cheese for household consumption. The community was deserted in winter, but in summer it received more than 9000 transhumant sheep and goats (20 farms).

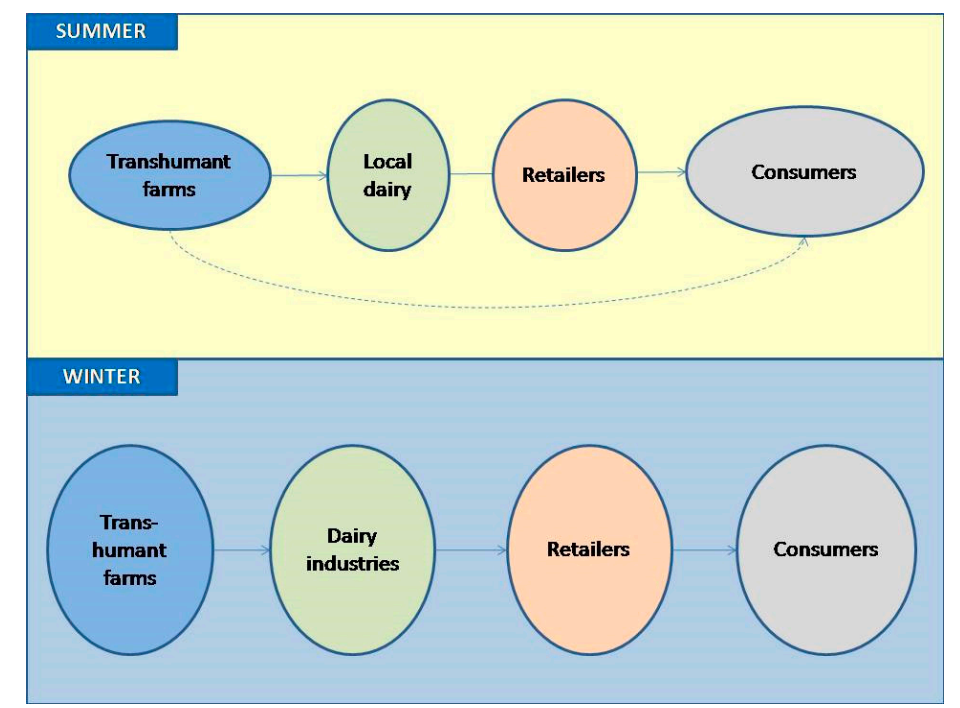

Figure 3. Illustration of the 'Artisanal' supply chain in the case study.

\subsubsection{Profile of the Dairies}

Dairy 1 ('Artisanal') was situated in a traditional stone building in the highlands, in the same community as Farm 3. It was a genuine family business, in operation for more than 40 years, starting from the father of the actual owner, who also reared sheep until the 1990s. The dairy operated only in summer, from late May until end of August. Gross revenues did not exceed 60,000€ and investments were low, as the building was recently renovated under the Leader+ initiative and the equipment did not include any machinery. It produced a variety of local cheeses ('kaseri', 'mizithra', 'graviera', 'kefalotyri') using traditional manual cheese-making techniques that highlighted the quality characteristics of locally produced milk. The dairy complied with all legal requirements for cheese production, but did not follow specific certification schemes. Products reached consumers directly or through selected delicatessen stores in cities nearby (Trikala, Larissa) and the owner transported the products himself. The dairy actually transformed the milk of 3 flocks rearing about 1500 ewes. Although its capacity was higher, the major obstacle was labor, as only the current owner worked there.

Dairy 2 ('Conventional') was situated in the town of Grevena in the lowlands and operated since 1960. From 1996, it specialized - not exclusively—in organic production. The industry collected and processed the milk of 50 sheep and goat farms, a proportion of which were transhumant, spending summer in mountains nearby and winter in Thessaly (about 150-200 km away). It also supervised the production of organic feedstuff for these farms in an area of about 2000 ha. The dairy combined traditional cheese-making with new technologies and developed an integrated traceability system and production lines certified by HACCP, ISO 9001:2000 and BRC. The total volume of production was 250 tons of organic and 600 tons of conventional cheeses, most of which were typical of Greece or of the specific area ('feta', ' 'graviera', 'kaseri', 'batzos', 'manouri', 'anevato' etc), but none specific to transhumance. Most of these products were exported (about $80 \%$ ), while only the remaining $20 \%$ was channeled to Greek consumers. The company worked closely with specialists in animal nutrition in order to provide specific guidelines and support to farms to produce high quality milk. It had its own milk collection network as well as storage, pasteurization, processing, maturing, standardization and storage facilities. The industry employed 35 persons and achieved an annual turnover of around 7 mil.€. 


\subsection{Qualitative Comparative Analysis of the Three SCS}

The in-depth interviews yielded important information about the motivation, operation and applicability of each SC. A significant part of discussions with farmers involved the requirements to undertake on-farm cheese making as a market-oriented activity. At the infrastructure level, 'Peasant' farmer informed that the necessary equipment was not costly, while also the establishment and licensing procedures of the dairy were relatively easy. Nevertheless, at the organizational/operational level, things were different. Significant labor was required, not only for the production of cheese but also for sales and transportation. This labor was deprived from other farm tasks and this is why the farmer had to recruit a second hired worker, since he had no help from other family members, and because trustworthy and skilled hired workers were hard to find in the area, he had to employ him throughout the year and not only during summer. On the contrary, 'Artisanal' farmer stated that he would not want to burden his farm with more obligations and 'Conventional' farmer went a step beyond by saying 'Why put additional pressure on my work?".

All respondents agreed that the summer milk of transhumant farms was of very high quality. 'Peasant' farmer said "I know that the unique taste of my products is due to vegetation, but I never made laboratory analyses to understand that", while the representative from 'Conventional' dairy had reservations about how a transhumance-specific product could be certified and produced regularly, achieving stable quality. 'Artisanal' farmer underlined that through his choice of this SC he wanted to support the local 'Artisanal' dairy and to maintain good personal relationships, but he did not actually believe that this choice had positive effects for transhumance in general. Moreover, 'Peasant' farmer stated that his clients did not prefer his cheese because he was transhumant, but because of its taste, freshness and overall quality. The owner of 'Artisanal' dairy affirmed that also his clients prefer his cheeses for their quality, " .....not for their story", while also 'Conventional' dairy agreed that a transhumance-specific product could potentially find its way in markets, but lots of work would be needed at the marketing level to convey the message of transhumance and respective ES.

All three farmers reported advantages for their choice, which did not make them doubt about it. For 'Peasant' farmer, two were the main benefits: the continuation of his family's cheese-making tradition and the reduction of his dependence on the dairy industry. Concerning the latter, the farmer delivered a small part of his summer milk also to the same Industry he sold in winter, in order to maintain a steady and trustworthy collaboration. However, if the situation with the Industry became worse, the farmer would consider expanding cheese production, by leaving the two hired workers in charge of the flock and him concentrating on cheese-making. 'Conventional' farmer stated that the steady cooperation with the Industry provided financial security. He reported no specific problems, because collaboration was based on a combination of formal arrangements (written contracts) and personal relationship (because of long-lasting collaboration). Improvements in his economic performance could come from farm management re-organization or from re-negotiating a better price with the Industry for his quality. In fact, he emphasized that many improvements could be done at the farm level, while also many things depended on the external environment, including taxation, subsidies and liquidity. 'Artisanal' farmer had based his choice on the good personal relationships with the Industry in the lowlands (six years of collaboration) and with the dairy in the highlands (his father sold his milk to the current owner's father). He benefited from acceptable milk prices, as he had agreed that the 'Artisanal' dairy would pay the same price as the winter industry $(1 € / \mathrm{kg})$. Since he was relieved from the burden of selling his milk, "I am free to organize my farm as I want to". In fact, he chose to use part of his labor to produce feedstuff for winter.

From the point of view of dairies, the situation was not significantly different. Dairy 1 ('Artisanal') focused on the production of specific, local, high-quality products, which provided a significant identity to the business. Working with transhumant farmers was an asset for the owner also because he came from a transhumant family. Having a steady clientele, he was not actually interested to approach broader markets-although there was confirmed demand-because this would require hiring help, potentially altering the quality of his products. His technical and practical knowledge had helped him 
ensure steady quality, but he believed that a certification system could not be applicable and would alter the character of his business. He only planned to make some small investments to improve cheese maturation and storage. For Dairy 2 ('Conventional'), working with transhumant farmers improved the overall reputation of the business. For this reason, the dairy disregarded occasional problems with irregular milk provision, especially in summer, when production was more dependent on weather conditions, as animals were kept outdoors. Transhumant farmers, in general, could not easily comply with the managerial advice provided by the scientific team of the dairy, mainly because it was difficult to integrate it in their extensive production pattern.

\subsection{Farm-Level Economic Effects of the Three Approaches}

Table 1 presents basic technical and economic indicators of the three farms. Flock sizes were between 570-660 ewes. All farms followed the same feeding strategy, relying exclusively on grazing during summer and on the provision of forage and concentrates in winter, with only few hours of grazing, depending on weather conditions. The difference was that 'Peasant' and 'Conventional' bought almost all feedstuff from markets, while 'Artisanal' produced lucerne and maize and only bought grains from markets. 'Peasant' and 'Artisanal' achieved milk yield at around $90 \mathrm{~kg} / \mathrm{ewe} / \mathrm{year}$, while 'Conventional' performed worse, producing $52.5 \mathrm{~kg} / \mathrm{ewe} / \mathrm{year}$. The reason behind this difference was farm management combined with differences among the breeds.

Table 1. Basic technical and economic indicators of the case study farms.

\begin{tabular}{lccc}
\hline & $\begin{array}{c}\text { Farm 1 } \\
\text { 'Peasant' }\end{array}$ & $\begin{array}{c}\text { Farm 2 } \\
\text { 'Conventional' }\end{array}$ & $\begin{array}{c}\text { Farm 3 } \\
\text { 'Artisanal' }\end{array}$ \\
\hline 1. Flock size (ewes) & 660 & 570 & 600 \\
\hline 3. Cultivated land (ha/ewe) & 0.003 & 0.005 & 0.032 \\
\hline 3. Milk yield (kg/ewe/year) & 89.4 & 52.6 & 93.7 \\
\hline 4. Milk sold to industries (kg/year) & 52,000 & 29,500 & 56,000 \\
\hline 5. Milk transformed to cheese (kg/year) & 7000 & 500 & 200 \\
\hline 6. Milk price & & & \\
\hline Winter (€/kg) & 1.02 & 0.95 & 1.00 \\
\hline Summer (€/kg) & 1.02 & 0.90 & 1.00 \\
\hline 7. Labor requirements (h/ewe) & 9.8 & 8.3 & 6.2 \\
\hline Family (h/ewe) & 3.1 & 4.5 & 1.7 \\
\hline Hired (h/ewe) & 6.7 & 3.8 & \\
\hline
\end{tabular}

'Peasant' differed from the other two as, obviously, a considerable part of milk production (about $12 \%$ ) was transformed to cheese on-farm. 'Peasant' achieved the highest price compared to the other two farms-despite his low sales quantity. 'Conventional', on the other hand, achieved the lowest price $(0.95 € / \mathrm{kg})$ in winter and even lower in summer $(0.90 € / \mathrm{kg})$. This was due to the low summer milk production (the farm produced 4.5 tons from late May until mid-July) and to the distance of the summer rangelands from the industry - which is situated in the lowlands. As explained also in the previous Section, 'Artisanal' sold summer and winter milk to the small dairy and to the industry at the same price $(1 € / \mathrm{kg})$.

Contrary to what would be expected, labor requirements per ewe did not decrease with flock size. This result reflects the organizational requirements of on-farm cheese making. 'Peasant' employed two hired workers throughout the year-although they were not needed for the whole period-while 'Conventional' only employed one person and 'Artisanal' hired a shepherd for 5 months in summer. 'Peasant' and 'Artisanal' employed one family member (the owner), while in 'Conventional' the owner 
was supported by his father and son. Note that 'Conventional' had low labor requirements for summer grazing, as the family was installed in a cabin in the rangeland.

Table 2 presents the synthesis of the gross revenue of each farm. As expected, milk was the most important product, with a contribution of $41.1 \%-48.6 \%$ followed by meat (lamb and ewe), contributing by $24.7 \%-32.2 \%$. Considering that the three farms sold their winter milk to industries and that summer milk production corresponded to the last 45-50 days (June until mid-July) of a lactation period of 210-220 days, it was normal to expect no significant differences. Cheese stood for a significant percentage (9\%) for 'Peasant' and was trivial for the other two. The contribution of subsidies was very important, ranging from $20.5 \%$ to $25.9 \%$ (coupled and decoupled Pillar I payments and mountainous areas Pillar II payment). Moreover, only for 'Peasant' milk and dairy products sales were more than half of the total farm income (54.7\%), which was due to the added value of milk transformed to cheese, while for this farm the contribution of subsidies was the lowest. On the contrary, for 'Conventional' the contribution of milk was the lowest along with the highest dependence on subsidies (25.9\%). 'Artisanal' achieved the highest gross revenue per ewe (202.3€/ewe).

Table 2. Synthesis of the gross revenue of the case study farms.

\begin{tabular}{|c|c|c|c|c|c|c|c|c|c|}
\hline & \multicolumn{3}{|c|}{$\begin{array}{c}\text { Farm } 1 \\
\text { 'Peasant' }\end{array}$} & \multicolumn{3}{|c|}{$\begin{array}{c}\text { Farm } 2 \\
\text { 'Conventional' }\end{array}$} & \multicolumn{3}{|c|}{$\begin{array}{c}\text { Farm } 3 \\
\text { 'Artisanal' }\end{array}$} \\
\hline & Total $(€)$ & $€ /$ ewe & $\%$ & $\begin{array}{c}\text { Total } \\
(\boldsymbol{\epsilon})\end{array}$ & $€ /$ ewe & $\%$ & $\begin{array}{c}\text { Total } \\
(\boldsymbol{\epsilon})\end{array}$ & $€ /$ ewe & $\%$ \\
\hline Milk & 53,040 & 80.4 & 45.7 & 27,800 & 48.8 & 41.1 & 56,000 & 98.2 & 48.6 \\
\hline Cheese & 10,500 & 15.9 & 9.0 & 600 & 1.1 & 0.9 & 350 & 0.6 & 0.3 \\
\hline Meat & $28,712.5$ & 43.5 & 24.7 & $21,766.8$ & 38.2 & 32.2 & 32,460 & 56.9 & 28.2 \\
\hline Subsidies & 23,800 & 36.1 & 20.5 & 17,500 & 30.7 & 25.9 & 26,500 & 46.5 & 23.0 \\
\hline TOTAL & $116,052.5$ & 175.8 & 100.0 & $67,666.8$ & 118.7 & 100.0 & 115,310 & 202.3 & 100.0 \\
\hline
\end{tabular}

Table 3 shows the production expenses per factor for each farm. Capital expenses were the highest for all three farms, as has been pointed out also by previous studies for extensive [7] and for intensive production [14,84]. For 'Peasant', purchased feedstuff was by far the most important cost driver, as the farm bought all feedstuff from markets, while 'Conventional' also grazed on cultivated pasture in winter, which reduced requirements for purchased forage. 'Artisanal' cultivated lucerne and maize and achieved significant feeding cost savings ( $60.6 € /$ ewe compared to $67.5 € /$ ewe for 'Conventional' and $93.9 € /$ ewe for 'Peasant'). Regarding fixed costs, they were trivial for 'Peasant', as infrastructure was obsolete, but higher for 'Conventional' and 'Artisanal' (12\% and $11.6 \%$ respectively). Their low percentage reflected the fact that the farms maintained an extensive character and did not invest in infrastructure: They did not use milking machines and in summer they kept animals in makeshift buildings. Labour costs per ewe were equal for 'Peasant' and 'Conventional', indicating that their labor management strategies have the same impact on farm profitability. For 'Artisanal', these costs were less (18.6€/ewe), as hired labor was only used for 5 months. As a combined result of all these, 'Artisanal' achieved the lowest production costs (111.5€/ewe) and 'Peasant' the highest (128.8 $€ /$ ewe).

Table 4 presents the basic financial results of the case study farms. In this Table, gross revenue does not include subsidies in order to provide a clear image of the true effectiveness of the three approaches. Therefore, the examination of these financial results shows different aspects of the economic performance of farms based only on market-related activities. The gross revenue per ewe was the highest for 'Artisanal' and the lowest for 'Conventional'. As a result, 'Peasant' and 'Artisanal' achieved net profit and 'Conventional' operated with net losses (-31.4€/ewe). For 'Peasant', this was mainly due to low fixed costs, considering that it was burdened with high feeding costs. On the contrary, 'Conventional' was not profitable because of low productivity combined with low milk prices, especially in summer. 'Artisanal' achieved the highest gross revenue along with the lowest costs and 
this was reflected in the highest net profit ( $36.5 € /$ ewe). The remaining three financial results followed a similar pattern. It is very important to highlight the negative $(-0.9 € / \mathrm{h})$ labor wage for 'Conventional', which shows that its operation was far from competitive and that radical managerial changes were required. On the other side, labor in 'Artisanal' was remunerated far higher than the usual hourly wage in Greece. Farm income in 'Conventional' was borderline positive ( $2.4 € /$ ewe), showing that resources were hardly remunerated and that the farm should have based its survival on subsidies. Gross margin was positive for all farms, revealing that they were in an acceptable financial position in the short run, but especially 'Artisanal' demonstrated the best potential.

Table 3. Costs breakdown of the case study farms.

\begin{tabular}{|c|c|c|c|c|c|c|c|c|c|}
\hline \multirow[t]{2}{*}{ Expenses } & \multicolumn{3}{|c|}{$\begin{array}{c}\text { Farm } 1 \\
\text { 'Peasant' }\end{array}$} & \multicolumn{3}{|c|}{$\begin{array}{c}\text { Farm } 2 \\
\text { 'Conventional' }\end{array}$} & \multicolumn{3}{|c|}{$\begin{array}{c}\text { Farm } 3 \\
\text { 'Artisanal' }\end{array}$} \\
\hline & Total (€) & $€ /$ ewe & $\%$ & $\begin{array}{l}\text { Total } \\
(€)\end{array}$ & $€ /$ ewe & $\%$ & $\begin{array}{c}\text { Total } \\
(€)\end{array}$ & $€ /$ ewe & $\%$ \\
\hline 1. Land rent & 3800 & 5.8 & 4.5 & 2600 & 4.6 & 3.8 & 3000 & 5.0 & 4.5 \\
\hline 2. Labor & 15,810 & 24.0 & 18.6 & 13,692 & 24.0 & 20.1 & 11,160 & 18.6 & 16.7 \\
\hline 3. Capital $(3 a+3 b)$ & 65,430 & 99.1 & 76.9 & 51,781 & 90.8 & 76.1 & 52,763 & 87.9 & 78.8 \\
\hline 3a. Variable capital & 64,660 & 98.0 & 76.0 & 43,601 & 76.5 & 64.1 & 44,980 & 75.0 & 67.2 \\
\hline Purchased feedstuff & 61,750 & 93.6 & 72.6 & 37,421 & 65.7 & 55.0 & 26,600 & 44.3 & 39.7 \\
\hline Animal production & 2700 & 4.1 & 3.2 & 5180 & 9.1 & 7.6 & 8580 & 14.3 & 12.8 \\
\hline Crop production & 210 & 0.3 & 0.2 & 1000 & 1.8 & 1.5 & 9800 & 16.3 & 14.6 \\
\hline 3b. Fixed capital & 770 & 1.2 & 0.9 & 8180 & 14.4 & 12.0 & 7783 & 13.0 & 11.6 \\
\hline TOTAL $(1+2+3)$ & 85,040 & 128.8 & 100.0 & 68,073 & 119.4 & 100.0 & 66,923 & 111.5 & 100.0 \\
\hline
\end{tabular}

Table 4. Financial results of the case study farms.

\begin{tabular}{ccccccc}
\hline & \multicolumn{2}{c}{$\begin{array}{c}\text { Farm 1 } \\
\text { 'Peasant' }\end{array}$} & \multicolumn{2}{c}{$\begin{array}{c}\text { Farm 2 } \\
\text { 'Conventional' }\end{array}$} & \multicolumn{2}{c}{$\begin{array}{c}\text { Farm 3 } \\
\text { 'Artisanal' }\end{array}$} \\
\cline { 2 - 7 } & Total (€) & $\boldsymbol{\epsilon} /$ ewe & Total (€) & €/ewe & Total (€) & €/ewe \\
\hline Gross revenue ${ }^{\mathbf{1}}$ & $92,252.5$ & 139.8 & $50,166.8$ & 88.0 & $88,810.0$ & 148.0 \\
\hline Total expenses & $85,040.0$ & 128.8 & $68,073.0$ & 119.4 & $66,923.0$ & 111.5 \\
\hline Net profit & 7212.5 & 10.9 & $-17,906.2$ & -31.4 & $21,887.0$ & 36.5 \\
\hline Labor wage (€/h) & 3.6 & & -0.9 & & 8.9 & \\
\hline Farm income & $27,592.5$ & 41.8 & 1365.8 & 2.4 & $38,897.0$ & 64.8 \\
\hline Gross margin & $27,592.5$ & 41.8 & 6565.8 & 11.5 & $43,830.0$ & 73.1 \\
\hline
\end{tabular}

\section{Discussion}

The analysis showed that all three SCs had advantages, but it cannot be supported that one SC was absolutely more effective than the others. Each one had different organizational requirements and entailed differences in strategy and everyday operation of farms. This was supported by the qualitative data collected through the interviews with the three farmers, none of which mentioned that they planned to shift from one SC to the other. Table 5 summarizes the key points of each SC by means of the assessment framework described in Section 2. 
Table 5. Qualitative assessment of the three SCs.

\begin{tabular}{|c|c|c|c|}
\hline & $\begin{array}{l}\text { Supply Chain } 1 \\
\text { 'Peasant' }\end{array}$ & $\begin{array}{l}\text { Supply Chain } 2 \\
\text { 'Conventional' }\end{array}$ & $\begin{array}{c}\text { Supply Chain } 3 \\
\text { 'Artisanal' }\end{array}$ \\
\hline $\begin{array}{c}\text { Quality of final } \\
\text { (manufactured dairy) } \\
\text { product }\end{array}$ & $\begin{array}{l}\text { High, not steady, not certified } \\
\text { quality. Conveys a clear } \\
\text { 'transhumance' message } \\
\text { directly to consumers }\end{array}$ & $\begin{array}{l}\text { Certified and steady quality. } \\
\text { The specific quality of } \\
\text { transhumance } \\
\text { (non-organoleptic } \\
\text { characteristics) is 'lost', } \\
\text { but traditional techniques are } \\
\text { integrated to new technologies }\end{array}$ & $\begin{array}{l}\text { High quality, embracing ES } \\
\text { provided by transhumance in } \\
\text { the area. Traditional } \\
\text { techniques are followed } \\
\text { and continued }\end{array}$ \\
\hline Economic performance & $\begin{array}{l}\text { Moderate, due to inefficient } \\
\text { use of hired labor and the lack } \\
\text { of family labor. High feeding } \\
\text { costs in summer (expensive } \\
\text { purchased feedstuff) }\end{array}$ & $\begin{array}{l}\text { Low, due to lack of farm } \\
\text { organization. Bargaining with } \\
\text { the dairy industry could } \\
\text { improve revenues. } \\
\text { Very low productivity. }\end{array}$ & $\begin{array}{l}\text { Satisfactory, as it combines } \\
\text { acceptable milk prices with } \\
\text { cost savings due to own } \\
\text { production of feedstuff. } \\
\text { The lowest hired } \\
\text { labor requirements }\end{array}$ \\
\hline $\begin{array}{l}\text { Representativeness } \\
\text { and Contribution }\end{array}$ & $\begin{array}{l}\text { Helps to maintain 'traditional' } \\
\text { agro-pastoralism, but can only } \\
\text { reach few consumers. Can } \\
\text { ensure the viability of } \\
\text { specific farms. }\end{array}$ & $\begin{array}{l}\text { More power to convey } \\
\text { 'transhumance' messages to } \\
\text { wider audiences. Can bring } \\
\text { financial stability to a large } \\
\text { number of farms under } \\
\text { specific conditions. }\end{array}$ & $\begin{array}{l}\text { Products are representative of } \\
\text { the territory and consumers } \\
\text { can be reached also in more } \\
\text { remote areas and settings. Can } \\
\text { establish steady networks with } \\
\text { local farms. }\end{array}$ \\
\hline
\end{tabular}

An important finding is that there were significant trade-offs between the choice of one approach and the overall operation of farms and that more in-depth examination is required. One relevant example involved the use of labor. 'Peasant' ensured high added value for its summer milk, but did not perform well, because there was not enough labor to accommodate this choice and the activity was not systematically organized. This was also pointed out by [67], who found that increased labor requirements of direct sales to consumers would lead to lower average profits. As labor costs are commonly reduced through the use of family labor, the extra labor required to produce cheese and sell it outside the farm threshold definitely deprived the 'Peasant' farm from this type of flexibility, in line with the findings of [76]. Therefore, poor management of labor exhausted the benefits from higher prices and lower involvement of middlemen [85].

On the other hand, economic performance of farms was not predominantly linked to increased product prices or added value. 'Peasant' and 'Artisanal' farms shared similar prices and only for 'Conventional' price was lower, particularly for summer milk. However, it is interesting to stress that a small part of the 'Peasant' milk was sold to a large industry - much like the 'Conventional' one - so the difference in prices was rather due to the choice of the specific industry and not to the overall approach. Therefore, actual economic benefits accrued due to non-price factors-as reported by 'Peasant' and 'Artisanal' farmers-and organizational characteristics of farms.

The economic performance of the three farms was a complex combination of multiple factors which need to be considered simultaneously. Negotiating prices with industries would definitely be a strategy towards increased profitability and also the choice of alternative feeding strategies would reduce feeding costs-which were the main cost driver in all farms-and increase yields, especially of 'Conventional' farm. Labor costs could definitely be reduced through undertaking only activities that can be supported by the existing workforce or which would justify the employment of more workers. Apart from these common recommendations, each farm could benefit from specific adjustments outlined in what follows. It should be particularly noted that financial results were satisfactory compared to previous research [7]. This is particularly important for 'Conventional' farm, 
which was the only one with net losses, therefore it would be expected that the farmer would want to shift towards another SC. His reluctance to do so demonstrated that he did not attribute his economic performance to his choice, but rather to the fact that subsidies counterbalance his losses, therefore the financial situation of his farm was not perceived as threatening.

The 'Conventional' approach had negative effects on the overall recognizability of the system, as the involvement of several actors isolated farms from consumers. Short SCs generally lead to a better understanding of transhumance and its operation. However, this did not necessarily mean that the 'agro-pastoral' message should be lost in a 'Conventional' approach, but rather that the communication of that message was in the hands of the industry and not of the farmer himself. In this context, the size of 'Conventional' industries and their ability to reach wider audiences, would make them ideal to bear the 'agro-pastoral myth' to consumers, thus contributing to increasing awareness. According to [86] the involvement of larger dairy enterprises, such as in the 'Conventional' SC in this study, does not necessarily entail adverse effects for farmers. On the contrary, she built on the example of the comté cheese in France to show that when larger dairies entered the supply chain, the product was valorized better, its quality (organoleptic characteristics) was improved and advertised, while dairy farmers benefited from a $25 \%$ higher milk price compared to the French average. On the other hand, following the issue raised by [44], 'Peasant' and 'Artisanal' SCs could convey the message more precisely, being the ones with a highly territorial character and embedded to the production system. Consequently, these 'territorial' SCs pertain to the paradigm described by [58] as 'the alternate food geography', with closer linkages to the specific characteristics of an area, entrepreneurship and environmental protection.

The 'Artisanal' approach was not just a compromise between the two other SCs, but rather showed how a diversification in milk sales could be an effective way to emphasize on optimizing the primary production side. The farm performed best among the three farms under examination, maintained an 'agro-pastoral identity' and contributed to the production of specific products by working with the respective dairy in summer, without allocating resources to diverse activities, which could lead to misuse of family labor.

Perhaps the key finding of the case study was that the choice among the three SCs is a complex issue. Since 'Peasant' farm had direct communication with consumers and 'Artisanal' actors conveyed the 'agro-pastoral' message more precisely, transhumance products could have an important market potential in 'territorial' SCs if institutional and organizational requirements for more systematic production were met. In addition, these two SCs could have implications for rural development, as 'Peasant' farms could become profitable and ensure their viability and 'Artisanal' farms and respective dairies could generate networks around their agro-pastoral identity. On the other hand, the 'Conventional' approach was the one which could reach more consumers and ensure stable revenues for a larger number of farms. From this point of view, a 'Conventional' SC also exhibits a high level of embeddedness, which is in line with the issue raised by [56] and [42]. Therefore, support in favor of one approach or the other is ambiguous and should take into account the characteristics of the region (existing infrastructure, other farms' strategies, local/regional/territorial development patterns etc.) and of farms and farmers (input endowments, culture, rationale, know-how and skills etc.).

In this context, the combination of the three approaches seems necessary. The intention to maintain more than one marketing channels was confirmed by 'Peasant' and 'Artisanal' farmers (as depicted in Figures 1 and 3) and-in parallel to what [76] reported for Australian meat producing farms and to the findings of [45] and [85] —it was affirmed that these approaches were compatible to 'Conventional', which is also depicted in Figures 1 and 3 for winter milk sales. A combination of approaches might, therefore, be the ideal solution for 'territorial' production-such as transhumance-specific dairy products-and this reinforces the argument by [67] that direct marketing to consumers may be more of a risk management tool than a tool for increasing profits. Indeed, interviews with all three farmers showed that the reduction of risks was one of their primary goals and that they found stability in each one of the three approaches, if the approach was based on long-term cooperation, personal 
relationships and mutual understanding. The transition of a 'Conventional' farm to 'Peasant' would unsettle this stability and the farm would have to find new organizational standards, which might not be compatible to its profile. The importance of organizational requirements in the success of such a transition was pointed out by [42] who stated that on-farm transformation and direct sales signaled a step forward for farmers, requiring a much more professional entrepreneurial attitude. Conversely, this financial stability would come for a price for 'Peasant' farm, as stopping to produce cheese on-farm would alter its agro-pastoral identity, which the farmer views as an asset.

The findings of this paper yielded information and knowledge which could serve to shed light on the potential benefits, drawbacks and problems of transhumance-specific dairy products. Some issues that need to be considered further include:

- Direct connection between transhumance and respective products through campaigns, in order to inform society about transhumance and the ES it provides, thus improving its recognizability and demand for its products;

- Traceability of the product in terms of transhumance origin, but with very careful steps and only if relevant research demonstrates that producers could efficiently undertake its requirements;

- Fair pricing of the high quality summer milk in order to improve the overall organization and performance of farms, thus stabilizing the provision of ES;

- Establishment of supporting and advisory services for farmers. Their role is essential to provide guidance in order to make rational choices at the organizational level. In 'Conventional' approach, the Industry provided such services to farmers, which undoubtedly contributed to the enhancement of overall performance of the SC. In the other two SCs, the availability of such services was scattered but farm profitability could definitely be strengthened through external help, from interventions at the central/regional level (advisory services, economic incentives, promotional activities). Especially for 'Conventional' farm, which lacks organizational efficiency, this type of support could be fundamental;

- Implementation of a wider territorial strategy contributing to the development of innovative activities. In this particular aspect, a 'territorial governance' approach [53] would be highly pertinent, as it would contribute to a more balanced allocation of power and expected benefits among stakeholders in all SCs. After all, effective management of SCs can lead to stability and sustainable operation [87]. Such a boost in 'territorial embeddedness' of SCs has also been pointed out by [56] as an effective strategy.

\section{Conclusions}

The specific economic characteristics of transhumance, which partly determine its economic performance and competitiveness, combined with the provision of multiple ES, demonstrate that it can improve its position in the market economy with appropriate structural adjustments and become a source of income and employment in mountainous and less-favored areas. The case study presented here regarding the systematic production of transhumance-specific dairy products, as an alternative to conventional dairy production in Greece, showed that the three farms under examination shared common features, namely the use of family labor, low dependence on fixed capital (investments in buildings and machinery) and relatively low demands for variable capital. In line with [57], a key outcome of this study is that a careful analysis of existing endowments and future requirements is necessary before deciding about the transition from one SC to the other and that a combination and/or co-existence of SCs in the area could be the optimal solution for farms and for the system as a whole.

The limitations of this study are predominantly connected to its methodological approach, as the findings of the case study cannot be generalized to other areas and production systems. However, the in-depth analysis demonstrated some basic points that need to be considered in the future in planning rural development or deciding about innovative activities relating to dairy production and linking products to their origin (territory, system, animal breed). In addition, the results demonstrate 
important aspects to be examined in order to increase the economic sustainability of extensive livestock farms. More qualitative analysis is required about the relationships between actors and, of course, quantitative research would help to consolidate the issues raised in this paper and to transform them to policy measures within the context of the CAP and to effective market strategies. All future research should be tailored to the specificities of transhumance and of the areas where it is practiced. Particular reference should be made to the necessity of relevant consumer research (qualitative and quantitative) in order to target consumer segments with specific preferences for transhumance products.

Author Contributions: A.R. conceptualized the case study and the analytical framework, launched the survey, analyzed data and wrote the draft manuscript. A.T. contributed to the analysis, interpretation of the results and literature review. G.A. contributed to the design of the case study and validated the results.

Funding: This paper is part of ongoing research within the Project 'iSAGE-Innovation for Sustainable Sheep and Goat Production in Europe" (http://www.isage.eu/), with financial support from the European Union's Horizon 2020 Research and Innovation Program under Grant Agreement No 679302.

Conflicts of Interest: The authors declare no conflicts of interest.

\section{References}

1. Ruiz, M.; Ruiz, J.P. Ecological history of transhumance in Spain. Biol. Conserv. 1986, 37, 73-86. [CrossRef]

2. Constantin, M. Capitalism and transhumance: A comparison of three pastoral market types in Europe (1950-2000). New Eur. Coll. Yearb. 2003, 11, 55-116.

3. Ispikoudis, I.; Soliou, M.K.; Papanastasis, V.P. Transhumance in Greece: Past, present and future prospects. Transhumance Biodivers. Eur. Mt. 2002, 211-226. Available online: http://www.llawern.com/addmat/2004\% 20Bunce\%20et\%20al.pdf (accessed on 30 September 2019).

4. Davies, J.; Hatfield, R. The economics of mobile pastoralism: A global summary. Nomadic Peoples 2007, 11, 91-116. [CrossRef]

5. Koocheri, A.; Gliessman, S.R. Pastoral nomadism, a sustainable system for grazing land management in Arid areas. J. Sustain. 2008, 25, 113.

6. Pardini, A.; Nori, M. Agro-silvo-pastoral system in Italy: Integration and divestification. In Pastoralism: Research, Policy and Practic; Springer: Berlin, Germany, 2011; pp. 1-10.

7. Ragkos, A.; Siasiou, A.; Galanopoulos, K.; Lagka, V. Mountainous grasslands sustaining traditional livestock systems: The economic performance of sheep and goat transhumance in Greece. Opt. Mediterr. 2004, 109, 575-579.

8. Papanastassis, V. Pastures and Livestock Development; Giahoudis and Giapoulis Publishing: Thessaloniki, Greece, 2009. (In Greek)

9. Vallerand, F. Seasonal Movements and Transhumant Farms in European Mediterranean. 2014. Available online: http://www.metakinoumena.gr/el/downloads/ (accessed on 30 September 2019).

10. Karatassiou, M.; Galidaki, G.; Ragkos, A.; Stefopoulos, K.; Lagka, V. Transhumant sheep and goat farming and the use of rangelands in Greece. Opt. Mediterr. Ser. A 2015, 115, 655-659.

11. Laga, V.; Ragkos, A.; Skapetas, V.; Mitsopoulos, I.; Kiritsi, S.; Abas, Z.; Mazaraki, K.; Bambidis, V. Current trends in the transhumant sheep and goat sector in Greece. Opt. Mediterr. Ser. A Mediterr. Semin. 2012, 102, 473-476.

12. Tzanopoulos, J.; Kallimanis, A.S.; Bella, I.; Labrianidis, L.; Sgardelis, S.; Pantis, J.D. Agricultural decline and sustainable development on mountain areas in Greece: Sustainability assessment of future scenarios. Land Use Policy 2011, 28, 585-593. [CrossRef]

13. Ragkos, A.; Lagka, V. The multifunctional character of sheep and goat transhumance in Greece. In Proceedings of the 8th Pan-Hellenic Rangeland Conference "Rangelands-Livestock farming: Research and Development. Employment prospects for young people”, Greece, Thessaloniki, 1-3 October 2014; pp. 47-52. (In Greek).

14. Ragkos, A.; Koutsou, S.; Manousidis, T. In search of strategies to face the economic crisis: Evidence from Greek farms. South Eur. Soc. Politics 2016, 21, 319-337. [CrossRef]

15. Parissi, Z.M.; Rapti, P.S.; Karatassiou, M. Grazing as a tool to maintain floristic diversity and herbage production in mountainous areas: A case study in north western Greece. Opt. Méditerranéennes Ser. A 2014, 109, 523-526. 
16. Siasiou, A.; Michas, V.; Mitsopoulos, I.; Bampidis, V.; Kiritsi, S.; Skapetas, V.; Lagka, V. Nutritional management of transhumant sheep and goats at the Region of Thessaly-Greece. In Proceedings of the 65th annual Meeting of the European Association for Animal Production, Copenhagen, Denmark, 25-29 August 2014.

17. Zdragas, A.; Papadopoulos, T.; Mitsopoulos, I.; Samouris, G.; Vafeas, G.; Boukouvala, E.; Ekateriniadou, L.; Mazaraki, K.; Alexopoulos, A.; Lagka, V. Prevalence, genetic diversity, and antimicrobial susceptibility profiles of Staphylococcus aureus isolated from bulk tank milk from Greek traditional ovine farms. Small Rumin. Res. 2015, 125, 120-126.

18. Ioannidou, M.; Karatassiou, M.; Ragkos, A.; Parissi, Z.M.; Mitsopoulos, I.; Sklavou, P.; Lagka, V.; Samouris, G. Effects on fatty acids profile of milk from transhumant small ruminants related to the floristic composition of mountainous rangelands. In Options Méditerranéennes, SERIES A: Mediterranean Seminars 2019 - Number 123; CIHEAM: Zaragoza, Spain, 2019; pp. 183-186.

19. Millenium Ecosystem Assessment. Esosystems and Human Well-Being: Current State and Trends Assessment; Isand Press: Washington, DC, USA, 2005.

20. Francioni, M.; Toderi, M.; Lai, R.; Trozzo, L.; Foresi, L.; Sciarra, F.; Avanzolini, P.; Sedić, E.; Budimir, K.; Santilocchi, R.; et al. Does transhumant sheep system provide ecosystem services for climate change adaptation in Mediterranean environment? Opt. Méditerranéennes 2016, 114, 103-107.

21. Varela, E.; Robles-Cruz, A.B. Ecosystem services and socio-economic benefits of Mediterranean grasslands. Opt. Méditerranéennes 2016, 114, 13-27.

22. Bernués, A.; Ruiz, R.; Olaizola, A.; Villalba, D.; Casasús, I. Sustainability of pasture based livestock farming systems in the European Mediterranean context: Synergies and trade-offs. Livest. Sci. 2011, 139, 44-57. [CrossRef]

23. Rodríguez-Ortega, T.; Oteros-Rozas, E.; Ripoll-Bosch, R.; Tichit, M.; Martín-López, B.; Bernués, A. Applying the ecosystem services framework to pasture-based livestock farming systems in Europe. Animal 2014, 8 , 1361-1372. [CrossRef]

24. Sklavou, P.; Karatassiou, M.; Parissi, Z.; Galidaki, G.; Ragkos, A.; Sidiropoulou, A. The Role of Transhumance on Land Use/Cover Changes in Mountain Vermio, Northern Greece: A GIS Based Approach. Not. Bot. Horti Agrobot. Cluj-Napoca 2017, 45, 589-596. [CrossRef]

25. Georgoudis, A.; Ligda, C. Small ruminant breeding programmes in Greece. Dev. Breed. Strateg. Lower Anim. Prod. Environ. 2000, 493-502. Available online: https://www.icar.org/Documents/technical_series/ICARTechnical-Series-no-3-Bella/Georgoudis.pdf (accessed on 30 September 2019).

26. Loukovitis, D.; Siasiou, A.; Mitsopoulos, I.; Lymberopoulos, A.G.; Laga, V.; Chatziplis, D. Genetic diversity of Greek sheep breeds and transhumant populations utilizing microsatellite markers. Small Rumin. Res. 2016, 136, 238-242. [CrossRef]

27. Papanastasis, V.P. Grazing intensity as an index of degradation in semi-natural ecosystems: The case of Psilorites mountain in Crete. In Indicators for Assessing Desertification in the Mediterranean; Enne, G., Ed.; Universitá di Sassari: Sassari, Italy, 1998; pp. 146-158.

28. Porqueddu, C.; Ates, S.; Louhaichi, M.; Kyriazopoulos, A.; del Pozo, A.; Ovalle, C.; Ewing, M.A.; Nichols, P.G.H. Grasslands in 'Old World' and 'New World' Mediterranean-climate zones: Past trends, current status and future research priorities. Grass Forage Sci. 2014, 71, 1-35. [CrossRef]

29. Available online: http://ayla.culture.gr/i_metakinoumeni_ktinotrofia/ (accessed on September 302019 ).

30. Galanopoulos, K.; Abas, Z.; Laga, V.; Hatziminaoglou, I.; Boyazoglu, J. The technical efficiency of transhumance sheep and goat farms and the effect of EU subsidies: Do small farms benefit more than large farms? Small Rumin. Res. 2011, 100, 1-7. [CrossRef]

31. Swinton, S.M.; Lupi, F.; Robertson, G.P.; Hamilton, S.K. Ecosystem services and agriculture: Cultivating agricultural ecosystems for diverse benefits. Ecol. Econ. 2007, 64, 245-252. [CrossRef]

32. Meloni, B.; Farinella, D. Cambiamenti ed evoluzione del pastoralismo in Sardegna. Agri. Regioni. Europa. 2015, 11, 89-93.

33. OECD. Multifunctionality: Towards an Analytical Framework; OECD: Paris, France, 2001.

34. Baumgärtner, J.; Tikubet, G.; Gilioli, G. Towards adaptive governance of common-pool mountainous agropastoral systems. Sustainability 2010, 2, 1448-1471. [CrossRef]

35. Ragkos, A.; Theodoridis, A. Valuation of Environmental and Social Functions of the Multifunctional Cypriot Agriculture. Land Use Policy 54C 2016, 54, 593-601. [CrossRef] 
36. Villanueva, A.J.; Gómez-Limón, J.A.; Arriaza, M.; Rodríguez-Entrena, M. The design of agri-environmental schemes: farmers' preferences in southern Spain. Land Use Policy 2015, 46, 142-154. [CrossRef]

37. Varela, E.; Górriz-Mifsud, E.; Ruiz-Mirazo, J.; López-i-Gelats, F. Payment for Targeted Grazing: Integrating Local Shepherds into Wildfire Prevention. Forests 2018, 9, 464. [CrossRef]

38. Ragkos, A.; Nori, M. The multifunctional pastoral systems in the Mediterranean EU and impact on the workforce. Opt. Mediterraneennes, Ser. A Mediterr. Sem. 2016, 114, 325-328.

39. Ragkos, A.; Abraham, E.M.; Papadopoulou, A.; Kyriazopoulos, A.P.; Parissi, Z.M.; Hadjigeorgiou, I. Effects of European Union policies on the sustainability of grazingland use in a typical Greek rural area. Land Use Policy 2017, 66, 196-204. [CrossRef]

40. Pulina, G.M.J.; Milán, M.P.; Lavín, A.; Theodoridis, E.; Morin, J.; Capote, D.L.; Thomas, A.H.D. Francesconi, and Gerardo Caja. Invited review: Current production trends, farm structures, and economics of the dairy sheep and goat sectors. J. Dairy Sci. 2018, 101, 6715-6729. [CrossRef]

41. Wiskerke, J. On places lost and places regained: Reflections on the alternative food geography and sustainable regional development. Int. Plan. Stud. 2009, 14, 369-387. [CrossRef]

42. Hinrichs, C.C. Embeddedness and Local Food Systems: Notes on Two Types of Direct Agricultural Market. J. Rural Stud. 2000, 16, 295-303. [CrossRef]

43. Sage, C. Social embeddedness and relations of regard: Alternative 'good food' networks in south-west Ireland. J. Rural Stud. 2003, 19, 47-60. [CrossRef]

44. Aubron, C.; Peglion, M.; Nozières, M.O.; Boutonnet, J.P. Quality schemes and pastoralism in France. Synergies and paradoxes. J. Alp. Res. Rev. De Géogr. Alp. 2014, 102, 2.

45. Ilbery, B.; Maye, D. Food supply chains and sustainability: Evidence from specialist food producers in the Scottish/English borders. Land Use Policy 2005, 22, 331-344. [CrossRef]

46. European Commission. Commission Implementing Regulation (EU) No 668/2014 of 13 June 2014 laying down rules for the application of Regulation (EU) No 1151/2012 of the European Parliament and of the Council on quality schemes for agricultural products and foodstuffs. Off. J. Eur. Union 2014, 171, 36-61.

47. European Commission. Commission Delegated Regulation(EU) No 665/2014 of 11 March 2014 supplementing Regulation (EU) No 1151/2012 of the European Parliament and of the Council with regard to conditions of use of the optional quality term 'mountain product'. Off. J. Eur. Union 2014, 179, 23-25.

48. Maye, D.; Kirwan, J.; Schmitt, E.; Keech, D.; Barjolle, D. PDO as a mechanism for reterritorialisation and Agri-Food governance: A comparative analysis of cheese products in the UK and Switzerland. Agriculture 2016, 6, 54. [CrossRef]

49. European Commission. Regulation (EU) No 1151/2012 of the European Parliament and of the Council of 21 November 2012 on quality schemes for agricultural products and foodstuffs. Off. J. Eur. Union 2012, 25, 31-59.

50. Weber, K.; Heinze, K.L.; DeSoucey, M. Forage for thought: Mobilizing codes in the movement for grass-fed meat and dairy products. Adm. Sci. Q. 2008, 53, 529-567. [CrossRef]

51. Available online: http://finistere.com/news/putting-out-to-pasture-the-future-of-dairy-in-america/ (accessed on 30 September 2019).

52. Available online: https://www.pastureforlife.org/news/launch-of-first-uk-made-100-grass-fed-pasture-forlife-organic-cheddar-at-dairy-tech-2019/ (accessed on 30 September 2019).

53. André, T.; Frédéric, W. Towards New Paths for Regional and Territorial Development in Rural Areas. Eur. Plan. Stud. 2015, 23, 650-677. [CrossRef]

54. Available online: http://ecdpm.org/great-insights/territorial-development-2/what-is-territorial-development/ (accessed on 30 September 2019).

55. Koutsou, S.; Partalidou, M.; Ragkos, A. Young farmers' social capital in Greece: Trust levels and collective actions. J. Rural Stud. 2014, 34, 204-211. [CrossRef]

56. Sonnino, R. Embeddedness in action: Saffron and the making of the local in southern Tuscany. Agric. Hum. Values 2007, 24, 61-74. [CrossRef]

57. Marescotti, A. Typical products and rural development: Who benefits from PDO/PGI recognition. In Proceedings of the 83rd EAAE Seminar Food Quality Products in the Advent of the 21st Century: Production, Demand and Public Policy, Chania, Greece, 4-7 September 2003; pp. 4-7.

58. Ilbery, B.; Kneafsey, M. Registering regional speciality food and drink products in the United Kingdom: The case of PDOs and PGIs. Area 2000, 32, 317-325. [CrossRef] 
59. Renting, H.; Marsden, T.K.; Banks, J. Understanding alternative food networks: Exploring the role of short food supply chains in rural development. Environ. Plan. A 2003, 35, 393-411. [CrossRef]

60. Botonaki, A.; Polymeros, K.; Tsakiridou, E.; Mattas, K. The role of food quality certification on consumers' food choices. Br. Food J. 2006, 108, 77-90. [CrossRef]

61. Fotopoulos, C.; Krystallis, A. Are quality labels a real marketing advantage? A conjoint application on Greek PDO protected olive oil. J. Int. Food Agribus. Mark. 2001, 12, 1-22. [CrossRef]

62. Skuras, D.; Vakrou, A. Consumers' willingness to pay for origin labelled wine: A Greek case study. Br. Food J. 2002, 104, 898-912. [CrossRef]

63. Stachtiaris, S.; Drichoutis, A.C.; Klonaris, S. Comparison of different methodologies for eliciting consumer willingness to pay for quality agricultural products. In Sustainable Agriculture and Food Production: Adaptations to a Changing Social, Economic and Institutional Environment, Proceedings of the 11th biannual conference of the Hellenic Association of Agricultural Economists, Thessaloniki, Greece, 26-27 November 2010; Hellenic Association of Agricultural Economists: Thessaloniki, Greece, 2010; pp. 235-248.

64. Anthopoulou, T. The concepts of "local" and "traditional" in the perceptions and food manufacturing practices of rural crafts-women. Rev. De La Fac. De Agron. 2013, 112, 1-10.

65. Galli, F.; Brunori, G. Short Food Supply Chains as drivers of sustainable development. Evidence Document. Document developed in the framework of the FP7 project FOODLINKS GA; No. 265287; Laboratorio di studi rurali Sismondi: Pisa, Italy, 2013; ISBN 978-88-90896-01-9.

66. OECD. Niche Markets as a Rural Development Strategy; OECD: Paris, France, 1995.

67. Kneafsey, M.; Venn, L.; Schmutz, U.; Balázs, B.; Trenchard, L.; Eyden-Wood, T.; Bos, E.; Sutton, G.; Blackett, M. Short food supply chains and local food systems in the EU. A state of play of their socio-economic characteristics. JRC Sci. Policy Rep. 2013, 123. [CrossRef]

68. Ragkos, A.; Karatasiou, M.; Georgousis, Z.; Parissi, Z.; Lagka, V. A traditional route of transhumant flocks in Northern Greece: Cultural aspects and economic implications. Opt. Mediterr. Ser. A Mediterr. Semin. 2016, 114, 345-348.

69. Lu, C.D.; Gangyi, X.; Kawas, J.R. Organic goat production, processing and marketing: Opportunities, challenges and outlook. Small Rumin. Res. 2010, 89, 102-109. [CrossRef]

70. Morris, C.; Evans, N. Cheese Makers Are Always Women': Gendered representations of farm life in the agricultural press. Gend. Place C. 2001, 8, 375-390. [CrossRef]

71. Ragkos, A.; Koutsou, S.; Theodoridis, A.; Manousidis, T.; Lagka, V. Labor management strategies in facing the economic crisis. Evidence form Greek livestock farms. New Medit 2018, 17, 59-71. [CrossRef]

72. Koutouzidou, G.; Ragkos, A.; Theodoridis, A.; Koutsou, S. Improving market outcomes: A qualitative assessment of the Greek dairy supply chain. J. Hell. Vet. Med Soc.. (under review).

73. Marsden, T.K.; Banks, J.; Bristow, G. Food supply chain approaches: Exploring their role in rural development. Sociol. Rural. 2000, 40, 424-438. [CrossRef]

74. Dubeuf, J.P. Structural, market and organisational conditions for developing goat dairy production systems. Small Rumin. Res. 2005, 60, 67-74. [CrossRef]

75. Yin, R. Case Study Research; Sage Publications: London, UK, 2003.

76. Broderick, S.; Wright, V.; Kristiansen, P. Cross-case analysis of producer-driven marketing channels in Australia. Br. Food J. 2001, 113, 1217-1228. [CrossRef]

77. Alonso, A.D.; O'Neill, M.A. Interest in maximisation and value-added produce: A preliminary study from Chilton County, Alabama. Br. Food J. 2001, 113, 637-655. [CrossRef]

78. Hadjigeorgiou, I. Past, present and future of pastoralism in Greece. Pastor. Res. Policy Pract. 2011, 1, 24. [CrossRef]

79. Papanastasis, V.P.; Mantzanas, K.; Dini-Papanastasi, O.; Ispikoudis, I. Traditional agroforestry systems and their evolution in Greece. In Agroforestry in Europe; Springer: Dordrecht, The Netherlands, 2009; pp. 89-109.

80. Barjolle, D.; Sylvander, B. Some factors of success for origin labelled products in agri-food supply chains in Europe: Market, internal resources and institutions. Econ. Soc. 2002, 25, 1441.

81. Pearson, D.; Henryks, J.; Trott, A.; Jones, P.; Parker, G.; Dumaresq, D.; Dyball, R. Local Food: Understanding Consumer Motivations in Innovative Retail Formats. Br. Food J. 2011, 113, 886-899. [CrossRef]

82. Cayre, P.; Depigny, S.; et Michelin, Y. Multifonctionnalite de l' agriculture: Quelle motivation de l' agriculture? Les Cah. De La Multifonctionnalite 2004, 5, 5-16. 
83. Ilbery, B.; Kneafsey, K. Product and Place: Promoting Quality Products and Services in the Lagging Rural Regions of the European Union. Eur. Urban Reg. Stud. 1998, 5, 329-341.

84. Theodoridis, A.; Ragkos, A.; Roustemis, D.; Galanopoulos, K.; Abas, Z.; Sinapis, E. Assessing technical efficiency of Chios sheep farms with data envelopment analysis. Small Rumin. Res. 2012, 107, 85-91. [CrossRef]

85. Lawson, R.; Guthrie, J.; Cameron, A.; Fischer, W.C. Creating Value through Cooperation: An Investigation of Farmers' Markets in New Zealand. Br. Food J. 2008, 110, 11-25. [CrossRef]

86. Dos Santos, A. Labelling mountain food products in Europe. In CPT-80830 MSc Thesis Knowledge, Technology and Innovation; Wageningen University: Wageningen, The Netherlands, 2007.

87. Brunori, G.; Galli, F.; Barjolle, D.; Van Broekhuizen, R.; Colombo, L.; Giampietro, M.; Kirwan, J.; Lang, T.; Mathijs, E.; Maye, D.; et al. Are local food chains more sustainable than global food chains? Consid. Assess. Sustain. 2016, 8, 449 .

(C) 2019 by the authors. Licensee MDPI, Basel, Switzerland. This article is an open access article distributed under the terms and conditions of the Creative Commons Attribution (CC BY) license (http://creativecommons.org/licenses/by/4.0/). 